\title{
Zinc and respiratory tract infections: Perspectives for COVID-19 (Review)
}

\author{
ANATOLY V. SKALNY ${ }^{1,2^{*}}$, LOTHAR RINK ${ }^{3 *}$, OLGA P. AJSUVAKOVA ${ }^{2,4}$, MICHAEL ASCHNER $^{1,5}$, \\ VIKTOR A. GRITSENKO ${ }^{6}$, SVETLANA I. ALEKSEENKO ${ }^{7,8}$, ANDREY A. SVISTUNOV ${ }^{1}$, DEMETRIOS PETRAKIS ${ }^{9}$, \\ DEMETRIOS A. SPANDIDOS ${ }^{10}$, JAN AASETH $^{1,11}$, ARISTIDIS TSATSAKIS ${ }^{1,9}$ and ALEXEY A. TINKOV ${ }^{1,2,6^{*}}$
}

\author{
${ }^{1}$ I.M. Sechenov First Moscow State Medical University (Sechenov University), 119146 Moscow; \\ ${ }^{2}$ Yaroslavl State University, 150003 Yaroslavl, Russia; ${ }^{3}$ Institute of Immunology, Medical Faculty, \\ RWTH Aachen University, D-52062 Aachen, Germany; ${ }^{4}$ Federal Research Centre of Biological Systems \\ and Agro-technologies of the Russian Academy of Sciences, 460000 Orenburg, Russia; ${ }^{5}$ Department of \\ Molecular Pharmacology, Albert Einstein College of Medicine, Bronx, NY 10461, USA; ${ }^{6}$ Institute of Cellular \\ and Intracellular Symbiosis, Russian Academy of Sciences, 460000 Orenburg; ${ }^{7}$ I.I. Mechnikov North-Western State \\ Medical University, 191015 St. Petersburg; ${ }^{8}$ K.A. Rauhfus Children's City Multidisciplinary Clinical Center \\ for High Medical Technologies, 191000 St. Petersburg, Russia; ${ }^{9}$ Center of Toxicology Science and Research, \\ ${ }^{10}$ Laboratory of Clinical Virology, Medical School, University of Crete, 71409 Heraklion, Greece; \\ ${ }^{11}$ Research Department, Innlandet Hospital Trust, 3159894 Brumunddal, Norway
}

Received March 23, 2020; Accepted April 13, 2020

DOI: $10.3892 / \mathrm{ijmm} .2020 .4575$

\begin{abstract}
In view of the emerging COVID-19 pandemic caused by SARS-CoV-2 virus, the search for potential protective and therapeutic antiviral strategies is of particular and urgent interest. Zinc is known to modulate antiviral and antibacterial immunity and regulate inflammatory response. Despite the lack of clinical data, certain indications suggest that modulation of zinc status may be beneficial in COVID-19. In vitro experiments demonstrate that $\mathrm{Zn}^{2+}$ possesses antiviral activity through inhibition of SARS-CoV RNA polymerase. This effect may underlie therapeutic efficiency of chloroquine known to act as zinc ionophore. Indirect evidence also indicates that $\mathrm{Zn}^{2+}$ may decrease the activity of angiotensin-converting enzyme 2 (ACE2), known to be the receptor for SARS-CoV-2. Improved antiviral immunity by zinc may also occur through up-regulation of interferon $\alpha$ production and increasing its antiviral activity. Zinc possesses anti-inflammatory activity by inhibiting NF- $\kappa \mathrm{B}$ signaling and modulation of regulatory
\end{abstract}

Correspondence to: $\operatorname{Dr}$ Alexey A. Tinkov, I.M. Sechenov First Moscow State Medical University (Sechenov University), 119146 Moscow, Russia

E-mail: tinkov.a.a@gmail.com

Professor Aristidis Tsatsakis, Center of Toxicology Science and Research, Medical School, University of Crete, Voutes, 71409 Heraklion, Greece

E-mail: tsatsaka@uoc.gr

*Contributed equally

Key words: zinc, coronavirus, SARS-CoV-2, pneumonia, immunity
T-cell functions that may limit the cytokine storm in COVID-19. Improved $\mathrm{Zn}$ status may also reduce the risk of bacterial co-infection by improving mucociliary clearance and barrier function of the respiratory epithelium, as well as direct antibacterial effects against $S$. pneumoniae. Zinc status is also tightly associated with risk factors for severe COVID-19 including ageing, immune deficiency, obesity, diabetes, and atherosclerosis, since these are known risk groups for zinc deficiency. Therefore, $\mathrm{Zn}$ may possess protective effect as preventive and adjuvant therapy of COVID-19 through reducing inflammation, improvement of mucociliary clearance, prevention of ventilator-induced lung injury, modulation of antiviral and antibacterial immunity. However, further clinical and experimental studies are required.

\section{Contents}

1. Introduction

2. Zinc and COVID-19

3. $\mathrm{Zn}$ and respiratory viruses

4. Pneumonia in adults and the elderly

5. Pediatric respiratory infections

6. Zinc and lung inflammation

7. Zinc and S. pneumoniae infection

8. Perspectives and conclusions

\section{Introduction}

Zinc is an essential metal being involved in a variety of biological processes due to its function as a cofactor, signaling molecule, and structural element. It is involved in the 
regulation of carbohydrate and lipid metabolism, as well as the functioning of the reproductive, cardiovascular, and nervous system (1). At the same time, the most critical role of zinc is demonstrated for the immune system. Briefly, zinc regulates proliferation, differentiation, maturation, and functioning of leukocytes and lymphocytes (2). Zinc plays a signaling role involved in the modulation of inflammatory responses (3). It is also a component of nutritional immunity (4). Correspondingly, alteration of zinc status significantly affects immune response resulting in increased susceptibility to inflammatory and infectious diseases including acquired immune deficiency syndrome, measles, malaria, tuberculosis, and pneumonia (5). Earlier data demonstrate that populational $\mathrm{Zn}$ status is associated with the prevalence of respiratory tract infections in children and adults $(6,7)$.

In view of the high prevalence of zinc deficiency worldwide (up to 17\%), its impact on population health is considered as a significant issue (8). Moreover, certain groups of people, including infants, especially preterm ones, and elderly, are considered to be at high risk of zinc deficiency and its adverse effects (9).

Under zinc deficiency condition, organisms are more susceptible to toxin-producing bacteria or enteroviral pathogens that activate guanylate and adenylate cyclases, stimulating chloride secretion, causing diarrhea and diminishing absorption of nutrients, thus exacerbating an already compromised mineral status. In addition, zinc deficiency may impair the absorption of water and electrolytes, delaying the termination of normally self-limiting gastrointestinal disease episodes (10). During chronic deficiency, the production of pro-inflammatory cytokines increases, influencing the outcome of a large number of inflammatory, metabolic, neurodegenerative and immune diseases (11). Diseases such as rheumatoid arthritis, diabetes (12), atherosclerosis and obesity (13), impaired cognitive function (14), as well as age-related macular degeneration (AMD) may be due to zinc deficiency, worsening chronic inflammation and triggering oxidative stress.

Coronaviridae were considered as the etiological agent in $6-29 \%$ of respiratory infections $(15,16)$, although the severity of the disease varies significantly on the particular virus and its virulence (17). The viruses from the Coronaviridae family are zoonotic viruses that can be transmitted from animals to humans. The bat is considered the reservoir for these viruses, but other intermediate animals can also transmit the virus to humans (18). COVID-19 is a coronavirus disease caused by the novel 2019-nCoV virus (now called SARS-CoV-2) that appeared for the first time in Wuhan, China at the end of 2019 (19). Despite a close relation other two highly pathogenic coronaviruses, MERS-CoV and SARS-CoV (20), SARS-CoV-2 expanded to the majority of countries (21). On 11 March 2020, WHO characterized COVID-19 as a pandemic (22). Currently, the prevalence of COVID-19 exceeds 1,521,200 cases resulting in 92,700 deaths worldwide (23).

COVID-19 predominantly affects the respiratory system resulting in pneumonia and acute respiratory distress syndrome (24), leading to the requirement of mechanical ventilation (25). In turn, advanced age, acute respiratory distress syndrome (ARDS) and mechanical ventilation are known to be associated with higher COVID-19 mortality (26). The risk is also increased by modern life in which individuals are exposed to a multitude of chemicals, even in low doses that in the long-term predispose to chronic diseases and metabolic disturbances (27-31). Preexisting chronic metabolic diseases including diabetes, cardiovascular diseases (32), and obesity (33) are considered as risk factors for increased COVID-19 susceptibility and mortality. It is proposed that the elderly are at higher risk of COVID-19 due to impaired immune function (34).

Due to the clearly demonstrated role of zinc in immunity (2), and impaired zinc status in ageing (35), metabolic diseases including diabetes, obesity, and cardiovascular diseases (13), it is speculated that zinc compounds may be used as an adjunct therapy in COVID-19 treatment (36) for increasing antiviral resistance (37). Of note, zinc was earlier suggested as the potential agent for immune support and prevention of H1N1 influenza ('swine flu') (38).

In view of lack of clinical data on preventive and/or therapeutic efficiency of zinc in COVID-19, as well as primary involvement of the respiratory system, in this review, we will discuss recent clinical data on the role of zinc in protection against bronchopulmonary infections, as well as the existing indications of the direct impact of zinc on nCoV-2019.

\section{Zinc and COVID-19}

In view of the global COVID-19 pandemic, potential protective effect of zinc is of particular interest. Zinc is considered as the potential supportive treatment in therapy of COVID-19 infection due to its immune modulatory effect, as well as direct antiviral effect (36). However, the existing data will be only mechanistically discussed in this review, as direct data on anti-COVID-19 effects of zinc are absent to date.

Specifically, $\mathrm{Zn}^{2+}$ cations especially in combination with $\mathrm{Zn}$ ionophore pyrithione were shown to inhibit SARS-coronavirus RNA polymerase (RNA dependent RNA polymerase, RdRp) activity by decreasing its replication (39). These important findings demonstrate that $\mathrm{Zn}^{2+}$ may be considered as the particular antiviral agent in COVID-19 treatment. Of note, recent trials have indicated efficiency of chloroquine antiviral activity as a treatment of COVID-19 (40), although the intimate mechanisms of its antiviral activity require further investigation (41). Earlier findings demonstrate that chloroquine is a zinc ionophore increasing $\mathrm{Zn}^{2+}$ flux into the cell (42). Moreover, the authors also propose that chloroquine-mediate zinc influx may underlie anticancer activity of the compound (42). Similarly, it was hypothesized that increasing intracellular $\mathrm{Zn}^{2+}$ concentration by chloroquine may also mediate its antiviral effect against SARS-CoV-2. In this view zinc supplementation without chloroquine might have similar positive effects without adverse side-effects of chloroquine treatment (43). Hypothetically, such an effect may be also observed using other zinc ionophores like quercetin and epigallocatechin-gallate (44) with substantially lower toxicity, although clinical trials supported by experimental in vitro studies are required to support this hypothesis.

Another Zn-related approach to modulation of COVID-19 may include targeting $\mathrm{Zn}$ ions in the structure of viral proteins. Particularly, it has been demonstrated that disulfiram-induced $\mathrm{Zn}^{2+}$ release from papain-like protease in MERS-CoV and SARS-CoV resulting in protein destabilization (45). In view of 
the presence of similar critical Zn-containing sites, Zn-ejector drugs (e.g., disulfiram) may be considered as potential antiviral agents (46) and components of targeted oxidation strategy in anti-SARS-CoV-2 treatment (47).

SARS-CoV-2 similarly to SARS-CoV requires angiotensin-converting enzyme 2 (ACE2) for entry into target cells (48). Therefore, modulation of ACE2 receptor was considered as the potential therapeutic strategy in COVID-19 treatment (49). Speth et al (50) demonstrated that zinc exposure $(100 \mu \mathrm{M})$ was shown to reduce recombinant human ACE-2 activity in rat lungs. Although this concentration is close to physiological values of total zinc, the modulating effect of zinc on SARS-CoV-2-ACE2 interaction seem to be only hypothetical (51).

Although neither coronavirus HCoV 229E (52) nor $\mathrm{HCoV}-\mathrm{OC} 43$ (53) infection caused a significant reduction in ciliary beat frequency, $\mathrm{HCoV} 229 \mathrm{E}$ induced ciliary dyskinesia resulting in impaired mucociliary clearance. The latter may not only alter viral particle removal, but also predispose to bacterial co-infection as observed for influenza virus (54). In turn, Zn supplementation was shown to improve ciliary length in bronchial epithelium of Zn-deficient rats (55), as well as increase ciliary beat frequency in vitro (56). Therefore, zinc may hypothetically ameliorate nCoV-2019-induced dysfunction of mucociliary clearance. Generally, zinc was shown to be essential for respiratory epithelium due to antioxidant and anti-inflammatory activity (57), as well as regulation of tight junction proteins ZO-1 and Claudin-1 (58), thus increasing its barrier functions. In turn, downregulation of tight junction protein complexes e.g., ZO-1 and Claudin-1 and reduction in barrier function aggravates viral and bacterial inflammatory processes (59). In addition, loss of TJ perm selectivity in the airways results in an un-controlled leakage of high molecular weight proteins and water into the airways, which results in the formation of alveolar edema and ARDS (60).

\section{Zn and respiratory viruses}

Despite limited data on the direct effect of zinc on SARS-CoV-2 and COVID-19, its antiviral effects were demonstrated in other viral diseases. Zinc was shown to have a significant impact on viral infections through modulation of viral particle entry, fusion, replication, viral protein translation and further release for a number of viruses including those involved in respiratory system pathology $(37,61)$. Specifically, increasing intracellular $\mathrm{Zn}$ levels through application of $\mathrm{Zn}$ ionophores such as pyrithione and hinokitiol significantly alters replication of picornavirus, the leading cause of common cold (62). These findings generally correspond to the earlier indications of suppressive effect of zinc on rhinovirus replication originating from the early 1970s (63). In addition, $\mathrm{Zn}$ treatment was shown to increase interferon $\alpha$ (IFN $\alpha$ ) production by leukocytes (64) and potentiate its antiviral activity in rhinovirus-infected cells (65). As antiviral activity of IFN $\alpha$ is mediated through JAK1/STAT1 downstream signaling and up-regulation of antiviral enzymes [e.g., latent ribonuclease (RNaseL) and protein kinase RNA-activated (PKR)] involved in viral RNA degradation and inhibition of viral RNA translation (66), recent findings allow to propose that these mechanisms may be stimulated by $\mathrm{Zn}^{2+}$.
These findings along with the existing data on the role of zinc in immunity raised interest to the potential use of zinc in prevention and/or treatment of common cold. A systematic review by Singh and Das (67) published in Cochrane database revealed a significant reduction in common cold duration, as well as the incidence rate ratio of developing common cold (IRR=0.64 (95\% CI: 0.47-0.88), $\mathrm{P}=0.006)$ in response to zinc supplementation. The results of meta-analysis demonstrated that $\mathrm{Zn}$ supplementation in the dose $>75 \mathrm{mg}$ /day significantly reduced duration of common colds (68), with $\mathrm{Zn}$ acetate being the most effective form (69).

Certain studies also revealed the association between Zn status and respiratory syncytial virus (RSV) infection. Particularly, it has been demonstrated that whole blood zinc was significantly lower in children with RSV pneumonia (70). Impaired zinc metabolism in perinatal alcohol exposure is associated with immunosuppression and altered alveolar macrophage activity resulting in increased susceptibility to RSV infection (71). In turn, Zn compounds were shown to inhibit respiratory syncytial virus replication and RSV plaque formation with a more than 1,000 -fold reduction at $10 \mu \mathrm{m} \mathrm{Zn}$ preincubation (72).

It is also notable that zinc deficiency was associated with higher mortality and adverse long-term outcome in influenza-MRSA bacterial superinfection (73), also underlining the importance of considering the risk of bacterial coinfection.

Despite the presence of experimental findings on the protective effect of zinc supplementation against respiratory virus infections, clinical and epidemiological data are still to be elaborated and systematized.

\section{Pneumonia in adults and the elderly}

Zinc is essential for the immune system and elderly people have an increased probability for zinc deficiency (74). Low $\mathrm{Zn}$ status was considered as the potential risk factor for pneumonia in elderly. Particularly, subjects with high serum $\mathrm{Zn}(>70 \mu \mathrm{g} / \mathrm{dl}$, i.e., approx. $10.8 \mu \mathrm{mol} / \mathrm{l})$ were characterized by reduced incidence of pneumonia [0.52 (0.36, 0.76), $\mathrm{P}<0.001]$, as well as lower disease duration and antibiotic administration as compared to low-Zn $(<70 \mu \mathrm{g} / \mathrm{ml})$ group (75), being also related to all-cause mortality (76). Serum $\mathrm{Zn}$ levels were $15 \%$ lower in cases of community-acquired pneumonia and advanced age, being also associated with pneumonia severity as evaluated by CURB-65 scores (77). The incidence of severe pneumonia was significantly higher in Irani patients with low Zn status, although the mean duration of fever, tachycardia, and tachypnea only tended to be longer, although not significant (78). Correspondingly, serum $\mathrm{Zn}$ levels were found deficient at the onset of acute respiratory failure with the lowest values observed in septic shock patients. However, no association between serum $\mathrm{Zn}$ values and day-30 mortality or period of stay in intensive care unit was observed (79).

The results of systematic analysis also confirmed the efficiency of intake of at least $75 \mathrm{mg} /$ day $\mathrm{Zn}$ in reduction of pneumonia symptom duration but not severity, with the response being more pronounced in adults than in children (80). At the same time, certain studies failed to reveal any improvement in pneumonia when administered along with standard antibiotic treatment, although the period of supplementation was only 4 days (81). 
A detailed study by Boudreault et al (82) demonstrated that low plasma $\mathrm{Zn}$ predisposes to ventilator-induced injury in intensive care, being related to the role of metallothionein system in lung protection. These data corroborate the results of the experimental study demonstrating aggravation of ventilation-induced lung injury in $\mathrm{Zn}$ deficient rats (83).

In Indian patients high plasma zinc levels were found to be associated with reduced mortality from sepsis as well as lower 48-h SOFA scores (84). Moreover, persistent low serum Zn levels were associated with increased risk of recurrent sepsis in critically ill patients (85).

Altogether, the existing data demonstrate an association between zinc status and pneumonia in adults and elderly, as well as its complications including respiratory failure, ventilator-induced injury, and sepsis.

\section{Pediatric respiratory infections}

Initial reports have postulated nearly exceptional susceptibility of elderly to SARS-CoV-2 infection allowing to propose natural resistance to COVID-19 in children (86). However, detailed analysis of the pediatric COVID-19 cases (87) and the emerging Russian experience indicate that children may be also severely affected by SARS-CoV-2. In view of high incidence of $\mathrm{Zn}$ deficiency in infants, the existing data on the association between $\mathrm{Zn}$ status and pneumonia in children is also discussed.

High incidence of pneumonia in developing countries has been considered as the consequence of zinc deficiency in the population (7). The incidence of low serum zinc in children with severe pneumonia was $80 \%$ (88). Correspondingly, a 2-fold lower level of serum $\mathrm{Zn}$ was observed in pediatric acute lower respiratory infection patients (89). Significantly lower serum zinc levels were observed in children with pneumonia complicated by sepsis, mechanical ventilation, and cases of lethality (90). Generally, indications of low zinc status in children with pneumonia provide a rationale for preventive $\mathrm{Zn}$ supplementation.

Particularly, Zn supplementation in developing countries reduced pneumonia morbidity by $19 \%(\mathrm{RR}=0.81 ; 95 \% \mathrm{CI}$ : $0.73,0.90)$, whereas a $15 \%$ decrease in pneumonia-specific mortality was not significant (91). A recent systematic review and meta-analysis published in Cochrane database demonstrated that $\mathrm{Zn}$ supplementation significantly reduced the incidence and prevalence of pneumonia in children by 13 and $41 \%$ (92).

In contrast to the demonstrated preventive effects of $\mathrm{Zn}$ supplementation, data on the therapeutic effect of zinc in treatment of childhood pneumonia are conflicting (93). Despite the earlier observed reduction of treatment failure risk (94) and case fatality $[\mathrm{RR}=0.67$ (95\% CI: 0.24-0.85)] (95) in children with severe pneumonia, a more recent study demonstrated that $\mathrm{Zn}$ supplementation in 2-24 months old children with radiologically verified pneumonia did not result in significant improvement of risk reduction of treatment failure (96). Moreover, Zn supplementation in $\mathrm{Zn}$-deficient children with pneumonia until achievement of normal serum $\mathrm{Zn}$ levels did not improve clinical appearance of the disease (97).

A number of studies revealed the potential efficiency of $\mathrm{Zn}$ supplementation in prevention of non-specified acute lower respiratory infections including bronchitis, bronchiolitis, pneumonitis. Specifically, supplementation with $10 \mathrm{mg}$ zinc gluconate in $\mathrm{Zn}$-deficient children resulted in a nearly twofold reduction of the number of episodes of acute lower respiratory infections as well as the time to recovery (98). In addition, Zn supplementation (30 mg/day) in Thai children significantly reduced severity of acute lower respiratory tract infections resulting in faster disease cessation and shorter hospital stay (99). A detailed meta-analysis demonstrated that $\mathrm{Zn}$ supplementation significantly decreased the incidence of acute lower respiratory infection defined according to specific clinical criteria in children aged $<5$ years (100).

In parallel, the impact of $\mathrm{Zn}$ supplementation in relation to upper respiratory tract infections was also demonstrated. Particularly, the number of upper respiratory tract infections in Colombian children was reduced by $73 \%$ in response to supplementation with $5 \mathrm{mg} \mathrm{Zn}$ in a 12-month randomized clinical trial (101). Certain studies also revealed protective effect of zinc supplementation against both acute upper and lower respiratory diseases in children $(102,103)$.

\section{Zinc and lung inflammation}

Inflammation plays the key role in COVID-19 pathogenesis both at local (pneumonia) and systemic (cytokine storm) levels, and the search for adequate anti-inflammatory agents is of particular importance (104).

Although the role of zinc in regulation of inflammatory response was discussed in detail in a number of reviews $(2,5)$, certain aspects of the regulatory role of zinc in pneumonia pathogenesis and lung inflammation are still to be elucidated. However, the existing data clearly demonstrate that $\mathrm{Zn}$ ions may possess anti-inflammatory effects in pneumonia thus limiting tissue damage and systemic effects.

Specifically, $\mathrm{Zn}$ deficiency in rats resulted in a significant increase in proinflammatory TNF $\alpha$ and VCAM-1 expression and lung tissue remodeling, being partially reversed by $\mathrm{Zn}$ supplementation (105). Zn deficiency also resulted in a significant alteration of lung epithelial cell barrier function through up-regulation of TNF $\alpha$, IFN $\gamma$, and FasR signaling and cellular apoptosis in vitro (106). Zn deficiency was shown to up-regulate acute phase response-related genes through stimulation of JAK-STAT signaling in lungs under septic conditions (107). Zinc and nitric oxide (NO)-metallothioneine (MT)-Zn pathways were shown to mediate lung injury in response to LPS or hyperoxia (108).

In turn, Zn pretreatment significantly reduced LPS-induced pulmonary endothelial cell damage and increased cell viability in vitro, as well as improved respiratory function as assessed by blood oxygen pressure and saturation (109). It has been demonstrated that $\mathrm{Zn}$ pretreatment significantly decreases LPS-induced neutrophil recruitment to the lungs thus reducing acute lung injury in mice (110).

It is also notable that zinc deficiency is associated with inflammatory alterations of lung extracellular matrix predisposing to fibrosis (111). This finding is of particular interest in view of the presence of interstitial pulmonary fibrosis in COVID-19 patients (112).

Certain studies revealed protective effect of zinc against lung injury in systemic inflammation including sepsis. 


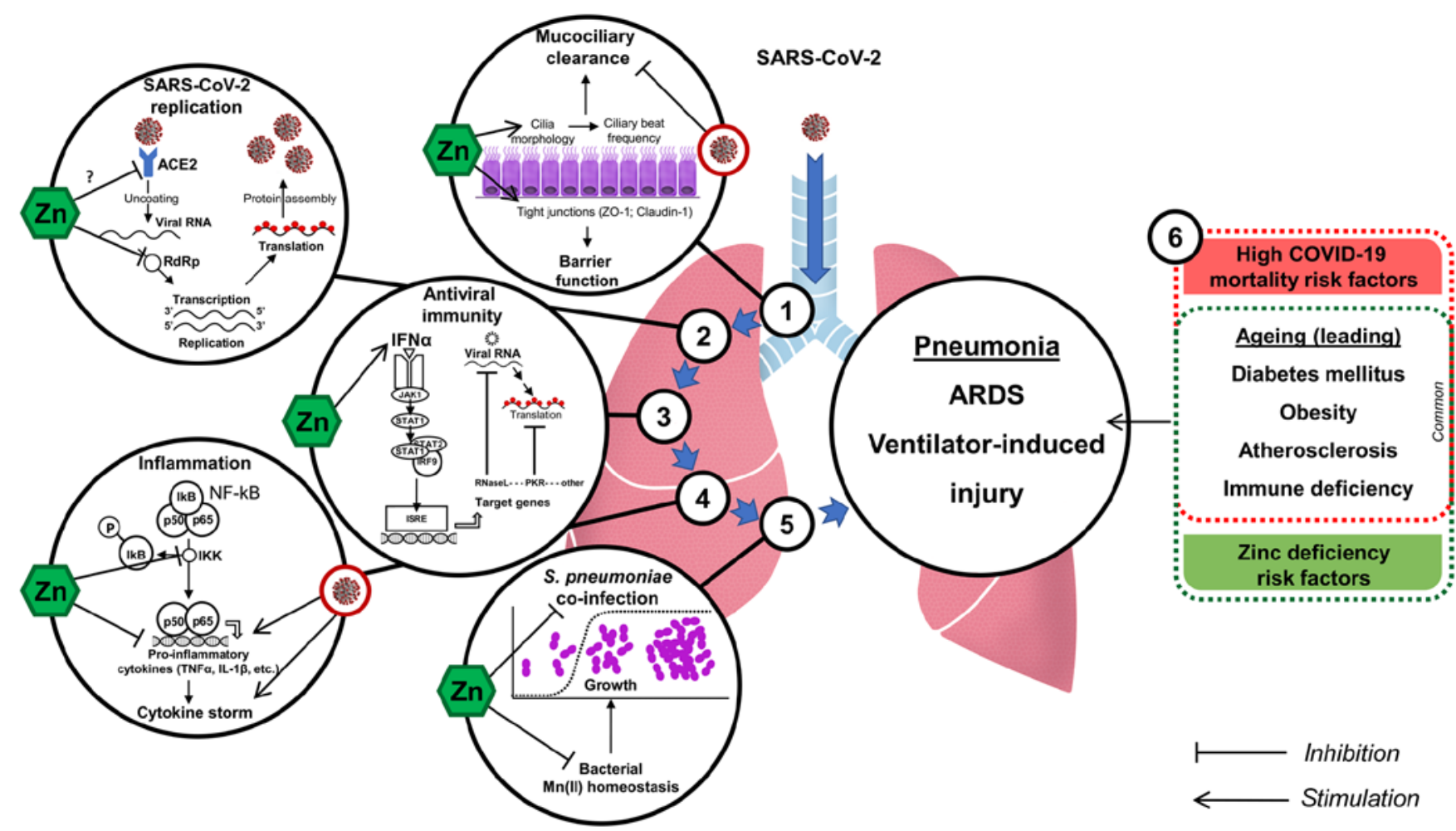

Figure 1. The proposed protective mechanisms of zinc in COVID-19. 1. Zinc significantly improves cilia morphology (54) and increases ciliary beat frequency (55) thus improving mucociliary clearance and removal of bacteria and virus-containing particles. By up-regulating tight junction proteins ZO-1 and claudin-1 (57) and increasing antioxidant activity of respiratory epithelia (56) zinc also increases barrier function of the latter. In turn, coronavirus infection was shown to impair mucociliary clearance (50) predisposing the lung for further viral and bacterial aggression. 2. Zinc may also possess antiviral activity through inhibition of RdRp and blocking further replication of viral RNA as demonstrated for SARS-CoV (38). Indirect evidence also indicates that $\mathrm{Zn}^{2+}$ may decrease activity of ACE2 (49), known to be the receptor for SARS-CoV-2 (47). 3. Modulation of antiviral immunity by zinc may also limit SARS-CoV-2 infection at least through up-regulation of IFN $\alpha$ production (63) and increasing its antiviral activity (64). The latter may be mediated through IFNa-induced JAK1/STAT1 signaling and up-regulation of antiviral proteins (RNaseL and PKR) known to degrade viral RNA and inhibit its translation (65). 4. Excessive inflammatory response resulting in overproduction of proiflammatory cytokines and cytokine storm is known to play a significant role in COVID-19 pathogenesis (103). In turn, zinc possesses anti-inflammatory activity through inhibition of IKK activity and subsequent NF-kB signaling resulting in down-regulation of proinflammatory cytokine production $(122,124)$. Modulation of regulatory T-cell functions by Zinc may also limit excessive inflammatory response $(125,126)$ as well as the downregulation of proinflammatory cytokine production $(127,123)$. 5. Given a high risk of bacterial co-infection in viral pneumonia (128), Zn-induced inhibition of S. pneumoniae growth through modulation of bacterial Mn(II) homeostasis (137) may also be beneficial. 6. Zinc status is also associated with risk factors for high COVID-19 mortality. Specifically, ageing, immune deficiency, as well as metabolic diseases such as obesity, diabetes, and atherosclerosis, are known to be both risk factors for high disease mortality $(31,32)$ and zinc deficiency $(149)$. In turn, $\mathrm{Zn}$ supplementation may

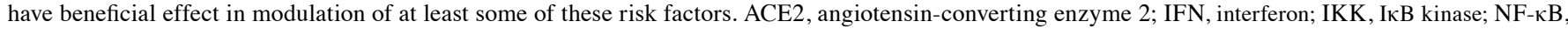
nuclear factor- $\mathrm{\kappa B}$; ARDS, acute respiratory distress syndrome.

Experimental data demonstrate that $\mathrm{Zn}$ deficiency increases susceptibility to systemic inflammation and sepsis-induced organ damage including lungs in a murine model of polymicrobial sepsis (113). In a model of polymicrobial sepsis $\mathrm{Zn}$ deficiency resulted in increased NF- $\mathrm{\kappa B}$ p65 mRNA expression and production in lungs resulting in up-regulation of target genes IL-1 $\beta$, TNF $\alpha$, and ICAM-1 (114), whereas Zn supplementation reduced neutrophil infiltration and MPO-mediated oxidative damage $(115,116)$. Modulation of ERK1/2 and $\mathrm{NF}-\kappa \mathrm{B}$ pathways was shown to be critical for protective effect of zinc in lungs under septic conditions (117).

Correspondingly, patients with sepsis were characterized by low serum $\mathrm{Zn}$ levels that may occur due to increased ZIP8 (SLC39A8) mRNA expression. Moreover, serum Zn concentrations inversely correlated with both disease severity and proinflammatory cytokines IL-6, IL-8, and TNF $\alpha$ (118). Reciprocal regulation of ZIP8 and NF- $\mathrm{kB}$ expression in response to TNF $\alpha$ or LPS exposure was demonstrated in lung epithelia and alveolar macrophages (119). In addition, ZIP8-deficient mice were characterized by increased airway neutrophil infiltration and elevated CXCL1 and IL-23 production (120).

$\mathrm{Zn}$-mediated respiratory protection was also demonstrated in models of toxic atmospheric pollutant exposure. Particularly, $\mathrm{Zn}$ deficiency in agricultural organic dust-exposed animals aggravated neutrophil migration and proinflammatory cytokine (TNF $\alpha$, IL-6, CXCL1) overproduction, as well as increased IL-23 and CXCL1 expression by macrophages due to NF- $\kappa B$ activation (121). In turn, $\mathrm{Zn}$ supplementation in cigarette smoke exposed mice significantly reduced the number of alveolar macrophages in bronchoalveolar lavage (122).

The observed anti-inflammatory effects of $\mathrm{Zn}$ in lung tissue seem to be mainly mediated by inhibition of NF- $\mathrm{KB}$ signaling through PKA-induced inhibition of Raf-1 and IкB kinase $\beta$ (IKK $\beta)(123,124)$ or A20-dependent inhibition (125). Moreover, Zn-induced modulation of T-cell activity may also play a significant role in limiting inflammatory response $(126,127)$. Lastly, zinc was shown to normalize the overproduction of proinflammatory cytokines induced by zinc deficiency on the epigenetic level $(124,128)$. 


\section{Zinc and S. pneumoniae infection}

Although COVID-19 is characterized by viral pneumonia caused by SARS-CoV-2 virus, bacterial co-infection may represent a significant issue due its high incidence in H1N1 influenza-associated pneumonia (129). Specifically, human coronavirus NL63 was associated with increased adherence of S. pneumoniae to epithelial cells (130). In turn, Streptococcus pneumoniae infection is considered as the most common cause of pneumonia.

Zinc is an essential component of antibacterial immunity (5). Particularly, Zn deficiency was associated with reduced killing activity of phagocytes in pneumococcal infection (131). In turn, $\mathrm{Zn}$ supplementation ameliorated the association between nasopharyngeal S.pneumoniae carriage and acute lower respiratory infection in children (132). Zn deficiency also predisposed to impaired immune response to Pneumococcal surface protein A, increased nasal S. pneumoniae colonization, and severe pneumococcal infection in mice (133) resulting in shorter survival time after infection (134). Correspondingly, patients with better immune response to 23-valent pneumococcal polysaccharide vaccine were characterized by significantly higher serum $\mathrm{Zn}$ levels (135). However, no effect (136) or serotype-specific effect (137) of $\mathrm{Zn}$ on antibody production in response to polyvalent pneumococcal vaccine was observed. $\mathrm{Zn}$ may also exert toxic effect on S. pneumoniae reducing its growth through interference with $\mathrm{Mn}$ (II) homeostasis and development of cytoplasmic manganese deficiency (138). The latter, in turn, increases bacterial susceptibility to oxygen-dependent killing by neutrophils (139).

A number of studies demonstrated antibacterial effect of zinc oxide nanoparticles (140). Particularly, $\mathrm{ZnO}$ was shown to inhibit both growth and biofilm formation by S. pneumoniae (141). Similar effect was observed for other bacterial agents involved in etiology of pneumonia, including $K$. pneumoniae (142), methicillin-resistant $S$. aureus (143), and $P$. aeruginosa (144). However, the potential antibacterial application of $\mathrm{ZnO}$-(NPs) may be limited due to their toxicity to human lung cells (145), as well as impairment of phagocytic activity of macrophages in bronchi and lungs (146).

When considering the relationship between S. pneumoniae and zinc, one should also note essentiality of $\mathrm{Zn}$ ions for bacteria. Specifically, adequate $\mathrm{Zn}$ uptake is required for normal bacterial growth and morphology, as well as colonization and virulence (147). Pneumococcal biofilm formation was also shown to be dependent on Zn bioavailability (148).

\section{Perspectives and conclusions}

The obtained data demonstrate that adequate zinc status of the individual increases immune reactivity. Correspondingly, inadequate zinc supply may predispose to infectious diseases of upper and lower respiratory tract. Although the therapeutic effects of $\mathrm{Zn}$ are considered as inconsistent, the existing evidence-based data indicate efficiency of $\mathrm{Zn}$ supplementation and improvement of $\mathrm{Zn}$ status in prevention of pneumonia and its complications due to anti-inflammatory effect of zinc.

Certain indirect indications of the potential antiviral effect of $\mathrm{Zn}$ against $\mathrm{nCoV}-2019$ exist, although their biomedical relevance is yet to be studied. In view of recent data on clinical course of the disease, it appears that adequate Zn status may possess protective effect as adjuvant therapy of COVID-19 through reducing lung inflammation, improvement of mucociliary clearance, prevention of ventilator-induced lung injury, modulation of antibacterial and antiviral immunity especially in elderly (Fig. 1). Further clinical and experimental studies are strongly required to elucidate the potential role of $\mathrm{Zn}$ deficiency in COVID-19 susceptibility, as well as effects of $\mathrm{Zn}$ supplementation, and the underlying mechanisms.

\section{Acknowledgements}

Not applicable.

\section{Funding}

The study was partially supported by the Russian Ministry of Science and Higher Education, Project no. 0856-2020-0008. MA was supported by NIH grants nos. NIEHS R0110563, R01ES07331 and NIEHS R01ES020852.

\section{Availability of data and materials}

Not applicable.

\section{Authors' contributions}

Conceptualization: AVS, LR, MA, JA, AT, AAT; validation, research, resources, data reviewing, and writing: AVS, LR, OPA, MA, VAG, SIA, AAS, DP, DAS, JA, AT, AAT; figure preparation and edition: AAT; review and editing: AVS, LR, MA, JA, AT, AAT. All authors read and approved the final manuscript.

\section{Ethics approval and consent to participate}

Not applicable.

\section{Patient consent for publication}

Not applicable.

\section{Competing interests}

DAS is the Editor-in-Chief for the journal, but had no personal involvement in the reviewing process, or any influence in terms of adjudicating on the final decision, for this article. The other authors declare that they have no competing interests.

\section{References}

1. Prasad AS: Discovery of Zinc for Human Health and Biomarkers of Zinc Deficiency. In: Molecular, Genetic, and Nutritional Aspects of Major and Trace Minerals. Collins JF (ed). Academic Press, Cambridge, pp241-260, 2017.

2. Wessels I, Maywald M and Rink L: Zinc as a gatekeeper of immune function. Nutrients 9: 1286, 2017.

3. Maywald M, Wessels I and Rink L: Zinc signals and immunity. Int J Mol Sci 18: 2222, 2017.

4. Haase H and Rink L: Multiple impacts of zinc on immune function. Metallomics 6: 1175-1180, 2014.

5. Gammoh NZ and Rink L: Zinc in infection and inflammation. Nutrients 9: 624, 2017. 
6. Aftanas LI, Bonitenko EYu, Varenik VI, Grabeklis AR, Kiselev MF, Lakarova EV, Nechiporenko SP, Nikolaev VA, Skalny AV and Skalnaya MG: Element status of population of Central Federal Region. In: Element status of population of Russia. Part II. Skalny AV and Kiselev MF (eds.) ELBI-SPb, Saint Petersburg, p430, 2011.

7. Walker CLF, Rudan I, Liu L, Nair H, Theodoratou E, Bhutta ZA O'Brien KL, Campbell H and Black RE: Global burden of childhood pneumonia and diarrhoea. Lancet 381: 1405-1416, 2013.

8. Bailey RL, West KP Jr and Black RE: The epidemiology of global micronutrient deficiencies. Ann Nutr Metab 66 (Suppl 2): 22-33, 2015.

9. Yasuda $\mathrm{H}$ and Tsutsui $\mathrm{T}$ : Infants and elderlies are susceptible to zinc deficiency. Sci Rep 6: 21850, 2016.

10. Wapnir RA: Zinc deficiency, malnutrition and the gastrointestinal tract. J Nutr 130 (Suppl): 1388S-1392S, 2000.

11. Bonaventura P, Benedetti G, Albarède F and Miossec P: Zinc and its role in immunity and inflammation. Autoimmun Rev 14 277-285, 2015.

12. Chabosseau P and Rutter GA: Zinc and diabetes. Arch Biochem Biophys 611: 79-85, 2016.

13. Olechnowicz J, Tinkov A, Skalny A and Suliburska J: Zinc status is associated with inflammation, oxidative stress, lipid, and glucose metabolism. J Physiol Sci 68: 19-31, 2018.

14. Kozlowski H,Luczkowski M, Remelli M and Valensin D: Copper, zinc and iron in neurodegenerative diseases (Alzheimer's, Parkinson's and prion diseases). Coord Chem Rev 256: 2129-2141, 2012.

15. Berry M, Gamieldien $\mathrm{J}$ and Fielding BC: Identification of new respiratory viruses in the new millennium. Viruses 7: 996-1019, 2015.

16. Peiris JSM: Coronaviruses. In: Clinical Virology. Richman DD, Whitley RJ and Hayden FG (eds). 4th edition. ASM Press, Washington, pp1244-1265, 2016.

17. Docea AO, Tsatsakis A, Albulescu D, Cristea O, Zlatian O, Vinceti M, Moschos SA, Tsoukalas D, Goumenou M, Drakoulis N, et al: A new threat from an old enemy: Re-emergence of coronavirus (Review). Int J Mol Med 45: 1631-1643, 2020.

18. Goumenou M, Spandidos DA and Tsatsakis A: [Editorial] Possibility of transmission through dogs being a contributing factor to the extreme Covid 19 outbreak in North Italy. Mol Med Rep 21: 2293-2295, 2020.

19. Lai CC, Shih TP, Ko WC, Tang HJ and Hsueh PR: Severe acute respiratory syndrome coronavirus 2 (SARS-CoV-2) and coronavirus disease-2019 (COVID-19): The epidemic and the challenges. Int J Antimicrob Agents 55: 105924, 2020.

20. Liu J, Cao R, Xu M, Wang X, Zhang H, Hu H, Li Y, Hu Z, Zhong $\mathrm{W}$ and Wang M: Hydroxychloroquine, a less toxic derivative of chloroquine, is effective in inhibiting SARS-CoV-2 infection in vitro. Cell Discov 6: 16, 2020.

21. Khachfe HH, Chahrour M, Sammouri J, Salhab H, Makki B and Fares MY: An epidemiological study on COVID-19: A rapidly spreading disease. Cureus 12: e7313, 2020.

22. World Health Organization (WHO): Coronavirus disease 2019 Events as they happen. WHO, Geneva, 2020. https://www.who.int/ emergencies/diseases/novel-coronavirus-2019/events-as-they-happen. Updated April 9, 2020.

23. World Health Organization (WHO): Coronavirus disease (COVID-2019). Situation report - 81. WHO, Geneva, 2020 https://www.who.int/docs/default-source/coronaviruse/situationreports/20200410-sitrep-81-covid-19.pdf. Accessed April 10, 2020.

24. Rothan HA and Byrareddy SN: The epidemiology and pathogenesis of coronavirus disease (COVID-19) outbreak. J Autoimmun 109: 102433, 2020.

25. Namendys-Silva SA: Respiratory support for patients with COVID-19 infection. Lancet Respir Med 8: e18, 2020.

26. Yang X, Yu Y, Xu J, Shu H, Xia J, Liu H, Wu Y, Zhang L, Yu Z, Fang M, et al: Clinical course and outcomes of critically ill patients with SARS-CoV-2 pneumonia in Wuhan, China: a single-centered, retrospective, observational study. Lancet Respir Med: Feb 24, 2020 (Epub ahead of print)

27. Docea AO, Goumenou M, Calina D, Arsene AL, Dragoi CM, Gofita E, Pisoschi CG, Zlatian O, Stivaktakis PD, Nikolouzakis TK, et al: Adverse and hormetic effects in rats exposed for 12 months to low dose mixture of 13 chemicals: RLRS part III. Toxicol Lett 310: 70-91, 2019.

28. Hernández AF, Docea AO, Goumenou M, Sarigiannis D Aschner M and Tsatsakis A: Application of novel technologies and mechanistic data for risk assessment under the real-life risk simulation (RLRS) approach. Food Chem Toxicol 137: 111123, 2020.
29. Fountoucidou P, Veskoukis AS, Kerasioti E, Docea AO, Taitzoglou IA, Liesivuori J, Tsatsakis A and Kouretas D: A mixture of routinely encountered xenobiotics induces both redox adaptations and perturbations in blood and tissues of rats after a long-term low-dose exposure regimen: The time and dose issue. Toxicol Lett 317: 24-44, 2019.

30. Tsatsakis AM, Kouretas D, Tzatzarakis MN, Stivaktakis $P$, Tsarouhas K, Golokhvast KS, Rakitskii VN, Tutelyan VA, Hernandez AF, Rezaee R, et al: Simulating real-life exposures to uncover possible risks to human health: A proposed consensus for a novel methodological approach. Hum Exp Toxicol 36 : 554-564, 2017.

31. Tsatsakis A, Tyshko NV, Docea AO, Shestakova SI, Sidorova YS, Petrov NA, Zlatian O, Mach M, Hartung T and Tutelyan VA: The effect of chronic vitamin deficiency and long term very low dose exposure to 6 pesticides mixture on neurological outcomes - A real-life risk simulation approach. Toxicol Lett 315: 96-106, 2019

32. Wu C, Chen X, Cai Y, Zhou X, Xu S, Huang H, Wu C, Chen X, Cai Y, Zhou X, et al: Risk factors associated with acute respiratory distress syndrome and death in patients with coronavirus disease 2019 pneumonia in Wuhan. JAMA Intern Med: Mar 13, 2020 (Epub ahead of print).

33. Huang R, Zhu L, Xue L, Liu L, Yan X, Wang J, Zhang B, Xu T, $\mathrm{Ji} \mathrm{F}$, et al: Clinical findings of patients with coronavirus disease 2019 in Jiangsu province, China: A retrospective, multi-center study. SSRN, 2020. https://ssrn.com/abstract=3548785. Accessed Febryary 28, 2020.

34. Jiang F, Deng L, Zhang L, Cai Y, Cheung CW and Xia Z: Review of the clinical characteristics of coronavirus disease 2019 (COVID-19). J Gen Intern Med: Mar 4, 2020 (Epub ahead of print).

35. Haase $H$ and Rink L: The immune system and the impact of zinc during aging. Immun Ageing 6: 9, 2009.

36. Zhang L and Liu Y: Potential interventions for novel coronavirus in China: A systematic review. J Med Virol 92: 479-490, 2020.

37. Read SA, Obeid S, Ahlenstiel C and Ahlenstiel G: The role of zinc in antiviral immunity. Adv Nutr 10: 696-710, 2019.

38. Sandstead $\mathrm{HH}$ and Prasad AS: Zinc intake and resistance to H1N1 influenza. Am J Public Health 100: 970-971, 2010.

39. te Velthuis AJ, van den Worm SH, Sims AC, Baric RS, Snijder EJ and van Hemert MJ: $\mathrm{Zn}(2+)$ inhibits coronavirus and arterivirus RNA polymerase activity in vitro and zinc ionophores block the replication of these viruses in cell culture. PLoS Pathog 6: e1001176, 2010.

40. Wang M, Cao R, Zhang L, Yang X, Liu J, Xu M, Shi Z, Hu Z, Zhong W and Xiao G: Remdesivir and chloroquine effectively inhibit the recently emerged novel coronavirus (2019-nCoV) in vitro. Cell Res 30: 269-271, 2020.

41. Liu J,Zheng X, Tong Q, Li W, Wang B, Sutter K, Trilling M, Lu M, Dittmer $U$ and Yang D: Overlapping and discrete aspects of the pathology and pathogenesis of the emerging human pathogenic coronaviruses SARS-CoV, MERS-CoV, and 2019-nCoV. J Med Virol 92: 491-494, 2020

42. Xue J, Moyer A, Peng B, Wu J, Hannafon BN and Ding WQ: Chloroquine is a zinc ionophore. PLoS One 9: e109180, 2014.

43. Guastalegname M and Vallone A: Could chloroquine/hydroxychloroquine be harmful in Coronavirus disease 2019 (COVID-19) treatment? Clin Infect Dis: Mar 24, 2020 (Epub ahead of print).

44. Dabbagh-Bazarbachi H, Clergeaud G, Quesada IM, Ortiz M, O'Sullivan CK and Fernández-Larrea JB: Zinc ionophore activity of quercetin and epigallocatechin-gallate: From Hepa 1-6 cells to a liposome model. J Agric Food Chem 62: 8085-8093, 2014.

45. Lin MH, Moses DC, Hsieh CH, Cheng SC, Chen YH, Sun CY and Chou CY: Disulfiram can inhibit MERS and SARS coronavirus papain-like proteases via different modes. Antiviral Res 150: 155-163, 2018.

46. Sargsyan K, Chen T, Grauffel C and Lim C: Identifying COVID-19 drug-sites susceptible to clinically safe Zn-ejector drugs using evolutionary/physical principles. OSF Preprints, 2020. https://osf.io/snuqf/. Accessed February 13, 2020.

47. Xu L, Tong J, Wu Y, Zhao S and Lin BL: Targeted oxidation strategy (TOS) for potential inhibition of Coronaviruses by disulfiram - a 70-year old anti-alcoholism drug. ChemRxiv (In Press).

48. Hoffmann M, Kleine-Weber H, Krüger N, Mueller MA, Drosten C and Pöhlmann S: The novel coronavirus 2019 (2019-nCoV) uses the SARS-coronavirus receptor ACE2 and the cellular protease TMPRSS2 for entry into target cells. bioRxiv (In Press). 
49. Zhang H, Penninger JM, Li Y, Zhong N and Slutsky AS: Angiotensin-converting enzyme 2 (ACE2) as a SARS-CoV-2 receptor: Molecular mechanisms and potential therapeutic target. Intensive Care Med 46: 586-590, 2020.

50. Speth R, Carrera E, Jean-Baptiste M, Joachim A and Linares A: Concentration-dependent effects of zinc on angiotensin-converting enzyme-2 activity (1067.4). FASEB J 28 (Suppl 1): 1067.4, 2014.

51. Chilvers MA, McKean M, Rutman A, Myint BS, Silverman M and O'Callaghan C: The effects of coronavirus on human nasal ciliated respiratory epithelium. Eur Respir J 18: 965-970, 2001.

52. Maret W: Analyzing free zinc(II) ion concentrations in cell biology with fluorescent chelating molecules. Metallomics 7: 202-211, 2015

53. Essaidi-Laziosi M, Brito F, Benaoudia S, Royston L, Cagno V, Fernandes-Rocha M, Piuz I, Zdobnov E, Huang S, Constant S, et al: Propagation of respiratory viruses in human airway epithelia reveals persistent virus-specific signatures. J Allergy Clin Immunol 141: 2074-2084, 2018.

54. Pittet LA, Hall-Stoodley L, Rutkowski MR and Harmsen AG: Influenza virus infection decreases tracheal mucociliary velocity and clearance of Streptococcus pneumoniae. Am J Respir Cell Mol Biol 42: 450-460, 2010.

55. Darma A, Ranuh RG, Merbawani W, Setyoningrum RA, Hidajat B, Hidayati SN, Andaryanto A and Sudarmo SM: Zinc supplementation effect on the bronchial cilia length, the number of cilia, and the number of intact bronchial cell in zinc deficiency rats. Indones Biomed J 12: 78-84, 2020

56. Woodworth BA, Zhang S, Tamashiro E, Bhargave G, Palmer JN and Cohen NA: Zinc increases ciliary beat frequency in calcium-dependent manner. Am J Rhinol Allergy 24: 6-10, 2010

57. Truong-Tran AQ, Carter J, Ruffin R and Zalewski PD: New insights into the role of zinc in the respiratory epithelium. Immunol Cell Biol 79: 170-177, 2001.

58. Roscioli E, Jersmann HP, Lester S, Badiei A, Fon A, Zalewski P and Hodge S: Zinc deficiency as a codeterminant for airway epithelial barrier dysfunction in an ex vivo model of COPD. Int J Chron Obstruct Pulmon Dis 12: 3503-3510, 2017.

59. Wittekindt $\mathrm{OH}$ : Tight junctions in pulmonary epithelia during lung inflammation. Pflugers Arch 469: 135-147, 2017.

60. Günzel D and Yu AS: Claudins and the modulation of tight junction permeability. Physiol Rev 93: 525-569, 2013.

61. Ishida $\mathrm{T}$ : Review on the role of $\mathrm{Zn}^{2+}$ ions in viral pathogenesis and the effect of $\mathrm{Zn}^{2+}$ ions for host cell-virus growth inhibition. Am J Biomed Sci Res: 2, AJBSR.MS.ID.000566, 2019.

62. Krenn BM, Gaudernak E, Holzer B, Lanke K, Van Kuppeveld FJM and Seipelt J: Antiviral activity of the zinc ionophores pyrithione and hinokitiol against picornavirus infections. J Virol 83: 58-64, 2009.

63. Korant BD, Kauer JC and Butterworth BE: Zinc ions inhibit replication of rhinoviruses. Nature 248: 588-590, 1974.

64. Cakman I, Kirchner H and Rink L: Zinc supplementation reconstitutes the production of interferon- $\alpha$ by leukocytes from elderly persons. J Interferon Cytokine Res 17: 469-472, 1997.

65. Berg K, Bolt G, Andersen H and Owen TC: Zinc potentiates the antiviral action of human IFN- $\alpha$ tenfold. J Interferon Cytokine Res 21: 471-474, 2001

66. Lin FC and Young HA: Interferons: Success in anti-viral immunotherapy. Cytokine Growth Factor Rev 25: 369-376, 2014.

67. Singh M and Das RR: Zinc for the common cold. Cochrane Database Syst Rev 2013: CD001364, 2013.

68. Hemilä H: Zinc lozenges and the common cold: A meta-analysis comparing zinc acetate and zinc gluconate, and the role of zinc dosage. JRSM Open 8: 2054270417694291, 2017.

69. Hemilä H: Zinc lozenges may shorten the duration of colds: A systematic review. Open Respir Med J 5: 51-58, 2011.

70. Che Z and Sun J: Investigation on relationship between whole blood zinc and Fe elements with children pneumonia caused by respiratory syncytial virus. Int J Lab Med 37: 2401-2402, 2016.

71. Johnson JK, Harris FL, Ping XD, Gauthier TW and Brown LAS: Role of zinc insufficiency in fetal alveolar macrophage dysfunction and RSV exacerbation associated with fetal ethanol exposure. Alcohol 80: 5-16, 2019.

72. Suara RO and Crowe JE Jr: Effect of zinc salts on respiratory syncytial virus replication. Antimicrob Agents Chemother 48 783-790, 2004

73. Kaynar AM, Andreas A, Maloy A, Austin W, Pitt BR, Gopal R and Alcorn JF: Zinc deficiency worsens the long-term outcome and exacerbates inflammation in a murine model of influenza-MRSA superinfection. Am J Respir Crit Care Med 199: A4130, 2019.
74. Haase H, Mocchegiani E and Rink L: Correlation between zinc status and immune function in the elderly. Biogerontology 7 : 421-428, 2006

75. Barnett JB, Hamer DH and Meydani SN: Low zinc status: A new risk factor for pneumonia in the elderly? Nutr Rev 68: 30-37, 2010.

76. Meydani SN, Barnett JB, Dallal GE, Fine BC, Jacques PF, Leka LS and Hamer DH: Serum zinc and pneumonia in nursing home elderly. Am J Clin Nutr 86: 1167-1173, 2007.

77. Bhat MH, Rather AB, Dhobi GN, Koul AN, Bhat FA and Hussain A: Zinc levels in community acquired pneumonia in hospitalized patients; a case control study. Egypt J Chest Dis Tuberc 65: 485-489, 2016

78. Saleh P, Sadeghpour A, Mirza-Aghazadeh-Attari M, Hatampour M, Naghavi-Behzad M and Tabrizi A: Relationship between plasma levels of zinc and clinical course of pneumonia. Tanaffos 16: 40-45, 2017

79. Linko R, Karlsson S, Pettilä V, Varpula T, Okkonen M, Lund V, Ala-Kokko T and Ruokonen E; FINNALI Study Group: Serum zinc in critically ill adult patients with acute respiratory failure. Acta Anaesthesiol Scand 55: 615-621, 2011.

80. Saigal P and Hanekom D: Does zinc improve symptoms of viral upper respiratory tract infection? EBP 23: 37-39, 2020.

81. Sharafi S and Allami A: Efficacy of zinc sulphate on in-hospital outcome of community-acquired pneumonia in people aged 50 years and over. Int J Tuberc Lung Dis 20: 685-688, 2016.

82. Boudreault F, Pinilla-Vera M, Englert JA, Kho AT, Isabelle C, Arciniegas AJ, Barragan-Bradford D, Quintana C, Amador-Munoz D, Guan J, et al; MICU Registry: Zinc deficiency primes the lung for ventilator-induced injury. JCI Insight 2: e86507, 2017

83. Chen X, Bian J and Ge Y: Zinc-deficient diet aggravates ventilation-induced lung injury in rats. J Biomed Res 26: 59-65, 2012.

84. Visalakshy J, Surendran S, Pillai MPG, Rajendran A and Sherif AA: Could plasma zinc be a predictor for mortality and severity in sepsis syndrome? Int J Res Med Sci 5: 3929-3934, 2017.

85. Hoeger J, Simon TP, Beeker T, Marx G, Haase H and Schuerholz T: Persistent low serum zinc is associated with recurrent sepsis in critically ill patients - A pilot study. PLoS One 12: e0176069, 2017.

86. Lee PI, Hu YL, Chen PY, Huang YC and Hsueh PR: Are children less susceptible to COVID-19? J Microbiol Immunol Infect: Feb 25, 2020 (Epub ahead of print).

87. Dong Y, Mo X, Hu Y, Qi X, Jiang F, Jiang Z and Tong S: Epidemiological characteristics of 2143 pediatric patients with 2019 coronavirus disease in China. Pediatrics (In Press).

88. Kumar N, Jayaprakash S and Kavitha D: Low serum zinc level - a possible marker of severe pneumonia. JMSCR 5: 21554-21570, 2017.

89. Islam SN, Kamal MM, Rahmatullah R, Sadi SKS and Ahsan M: Serum zinc levels in children with acute respiratory infections: Association with sociodemography and nutritional status. Clin Nutr Exp 22: 11-18, 2018

90. Saleh NY and Abo El Fotoh WMM: Low serum zinc level: The relationship with severe pneumonia and survival in critically ill children. Int J Clin Pract 72: e13211, 2018.

91. Yakoob MY, Theodoratou E, Jabeen A, Imdad A, Eisele TP, Ferguson J, Jhass A, Rudan I, Campbell H, Black RE, et al: Preventive zinc supplementation in developing countries: Impact on mortality and morbidity due to diarrhea, pneumonia and malaria. BMC Public Health 11 (Suppl 3): S23, 2011.

92. Lassi ZS, Moin A and Bhutta ZA: Zinc supplementation for the prevention of pneumonia in children aged 2 months to 59 months. Cochrane Database Syst Rev 12: CD005978, 2016.

93. Das RR, Singh M and Shafiq N: Short-term therapeutic role of zinc in children $<5$ years of age hospitalised for severe acute lower respiratory tract infection. Paediatr Respir Rev 13: 184-191, 2012.

94. Basnet S, Shrestha PS, Sharma A, Mathisen M, Prasai R, Bhandari N, Adhikari RK, Sommerfelt H, Valentiner-Branth P and Strand TA; Zinc Severe Pneumonia Study Group: A randomized controlled trial of zinc as adjuvant therapy for severe pneumonia in young children. Pediatrics 129: 701-708, 2012.

95. Srinivasan MG, Ndeezi G, Mboijana CK, Kiguli S, Bimenya GS, Nankabirwa V and Tumwine JK: Zinc adjunct therapy reduces case fatality in severe childhood pneumonia: A randomized double blind placebo-controlled trial. BMC Med 10: 14, 2012. 
96. Bagri NK, Bagri N, Jana M, Gupta AK, Wadhwa N, Lodha R, Kabra SK, Chandran A, Aneja S, Chaturvedi MK, et al: Efficacy of oral zinc supplementation in radiologically confirmed pneumonia: Secondary analysis of a randomized controlled trial. J Trop Pediatr 64: 110-117, 2018.

97. Yuan X, Qian SY, Li Z and Zhang ZZ: Effect of zinc supplementation on infants with severe pneumonia. World J Pediatr 12: 166-169, 2016.

98. Shah UH, Abu-Shaheen AK, Malik MA, Alam S, Riaz M and Al-Tannir MA: The efficacy of zinc supplementation in young children with acute lower respiratory infections: A randomized double-blind controlled trial. Clin Nutr 32: 193-199, 2013.

99.Rerksuppaphol S and Rerksuppaphol L: A randomized controlled trial of zinc supplementation in the treatment of acute respiratory tract infection in Thai children. Pediatr Rep 11: 7954, 2019.

100. Roth DE, Richard SA and Black RE: Zinc supplementation for the prevention of acute lower respiratory infection in children in developing countries: Meta-analysis and meta-regression of randomized trials. Int J Epidemiol 39: 795-808, 2010.

101.Martinez-Estevez NS, Alvarez-Guevara AN and Rodriguez-Martinez CE: Effects of zinc supplementation in the prevention of respiratory tract infections and diarrheal disease in Colombian children: A 12-month randomised controlled trial. Allergol Immunopathol (Madr) 44: 368-375, 2016.

102. Aggarwal R, Sentz J and Miller MA: Role of zinc administration in prevention of childhood diarrhea and respiratory illnesses: A meta-analysis. Pediatrics 119: 1120-1130, 2007.

103. Khera D, Singh S, Purohit P, Sharma P and Singh K: Prevalence of Zinc deficiency and effect of Zinc supplementation on prevention of acute respiratory infections: A non randomized open label study. SSRN, 2018. https://ssrn.com/ abstract=3273670. Accessed October 26, 2018.

104. Mehta P, McAuley DF, Brown M, Sanchez E, Tattersall RS and Manson JJ; HLH Across Speciality Collaboration, UK COVID-19: Consider cytokine storm syndromes and immunosuppression. Lancet 395: 1033-1034, 2020.

105. Biaggio VS, Pérez Chaca MV, Valdéz SR, Gómez NN and Gimenez MS: Alteration in the expression of inflammatory parameters as a result of oxidative stress produced by moderate zinc deficiency in rat lung. Exp Lung Res 36: 31-44, 2010.

106. Bao S and Knoell DL: Zinc modulates cytokine-induced lung epithelial cell barrier permeability. Am J Physiol Lung Cell Mol Physiol 291: L1132-L1141, 2006.

107.Liu MJ, Bao S, Napolitano JR, Burris DL, Yu L, Tridandapani S and Knoell DL: Zinc regulates the acute phase response and serum amyloid A production in response to sepsis through JAK-STAT3 signaling. PLoS One 9: e94934, 2014.

108. St Croix CM, Leelavaninchkul K, Watkins SC, Kagan VE and Pitt BR: Nitric oxide and zinc homeostasis in acute lung injury. Proc Am Thorac Soc 2: 236-242, 2005.

109. Krones CJ, Klosterhalfen B, Butz N, Hoelzl F, Junge K, Stumpf M, Peiper C, Klinge U and Schumpelick V: Effect of zinc pretreatment on pulmonary endothelial cells in vitro and pulmonary function in a porcine model of endotoxemia. J Surg Res 123: 251-256, 2005.

110. Wessels I, Pupke JT, von Trotha KT, Gombert A, Himmelsbach A, Fischer HJ, Jacobs MJ, Rink L and Grommes J: Zinc supplementation ameliorates lung injury by reducing neutrophil recruitment and activity. Thorax 75: 253-261, 2020.

111. Biaggio VS, Salvetti NR, Pérez Chaca MV, Valdez SR, Ortega HH, Gimenez MS and Gomez NN: Alterations of the extracellular matrix of lung during zinc deficiency. Br J Nutr 108: 62-70, 2012.

112. Luo W, Yu H, Gou J, Li X, Sun Y, Li J and Liu L: Clinical pathology of critical patient with novel Coronavirus pneumonia (COVID-19). Preprints 2020: 2020020407, 2020.

113. Knoell DL, Julian MW, Bao S, Besecker B, Macre JE, Leikauf GD, DiSilvestro RA and Crouser ED: Zinc deficiency increases organ damage and mortality in a murine model of polymicrobial sepsis. Crit Care Med 37: 1380-1388, 2009.

114. Bao S, Liu MJ, Lee B, Besecker B, Lai JP, Guttridge DC and Knoell DL: Zinc modulates the innate immune response in vivo to polymicrobial sepsis through regulation of NF-kappaB. Am J Physiol Lung Cell Mol Physiol 298: L744-L754, 2010.

115. Nowak JE, Harmon K, Caldwell CC and Wong HR: Prophylactic zinc supplementation reduces bacterial load and improves survival in a murine model of sepsis. Pediatr Crit Care Med 13: e323-e329, 2012.
116. Ganatra HA, Varisco BM, Harmon K, Lahni P, Opoka A and Wong HR: Zinc supplementation leads to immune modulation and improved survival in a juvenile model of murine sepsis. Innate Immun 23: 67-76, 2017.

117. Slinko S, Piraino G, Hake PW, Ledford JR, O'Connor M, Lahni P, Solan PD, Wong HR and Zingarelli B: Combined zinc supplementation with proinsulin C-peptide treatment decreases the inflammatory response and mortality in murine polymicrobial sepsis. Shock 41: 292-300, 2014.

118. Besecker BY, Exline MC, Hollyfield J, Phillips G, Disilvestro RA, Wewers MD and Knoell DL: A comparison of zinc metabolism, inflammation, and disease severity in critically ill infected and noninfected adults early after intensive care unit admission. Am J Clin Nutr 93: 1356-1364, 2011.

119. Liu MJ, Bao S, Gálvez-Peralta M, Pyle CJ, Rudawsky AC, Pavlovicz RE, Killilea DW, Li C, Nebert DW, Wewers MD, et al: ZIP8 regulates host defense through zinc-mediated inhibition of NF-кB. Cell Rep 3: 386-400, 2013.

120. Hall SC, Smith DR, Katafiasz DM, Bailey KL and Knoell DL: Novel role of zinc homeostasis in IL-23 regulation and host defense following bacterial infection. J Immunol 202 (Suppl 1): 62.6, 2019.

121. Knoell DL, Smith DA, Sapkota M, Heires AJ, Hanson CK, Smith LM, Poole JA, Wyatt TA and Romberger DJ: Insufficient zinc intake enhances lung inflammation in response to agricultural organic dust exposure. J Nutr Biochem 70: 56-64, 2019.

122.Lang CJ, Hansen M, Roscioli E, Jones J, Murgia C, Leigh Ackland M, Zalewski P, Anderson G and Ruffin R: Dietary zinc mediates inflammation and protects against wasting and metabolic derangement caused by sustained cigarette smoke exposure in mice. Biometals 24: 23-39, 2011.

123. von Bülow V, Dubben S, Engelhardt G, Hebel S, Plümäkers B, Heine H, Rink L and Haase H: Zinc-dependent suppression of TNF- $\alpha$ production is mediated by protein kinase A-induced

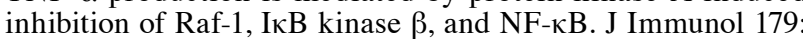
4180-4186, 2007.

124. Wessels I, Haase H, Engelhardt G, Rink L and Uciechowski P: Zinc deficiency induces production of the proinflammatory cytokines IL-1 $\beta$ and TNF $\alpha$ in promyeloid cells via epigenetic and redox-dependent mechanisms. J Nutr Biochem 24: 289-297, 2013.

125. Prasad AS, Bao B, Beck FW and Sarkar FH: Zinc-suppressed inflammatory cytokines by induction of A20-mediated inhibition of nuclear factor- $\kappa \mathrm{B}$. Nutrition 27: 816-823, 2011.

126. Wellinghausen N, Martin M and Rink L: Zinc inhibits interleukin-1-dependent $\mathrm{T}$ cell stimulation. Eur J Immunol 27: 2529-2535, 1997.

127. Rosenkranz E, Metz CH, Maywald M, Hilgers RD, Weßels I, Senff T, Haase H, Jäger M, Ott M, Aspinall R, et al: Zinc supplementation induces regulatory $\mathrm{T}$ cells by inhibition of Sirt-1 deacetylase in mixed lymphocyte cultures. Mol Nutr Food Res 60: 661-671, 2016.

128. Kahmann L, Uciechowski P, Warmuth S, Plümäkers B, Gressner AM, Malavolta M, Mocchegiani E and Rink L: Zinc supplementation in the elderly reduces spontaneous inflammatory cytokine release and restores $\mathrm{T}$ cell functions. Rejuvenation Res 11: 227-237, 2008.

129. Kim H: Outbreak of novel coronavirus (COVID-19): What is the role of radiologists? Eur Radiol: Feb 18, 2020 (Epub ahead of print).

130. Golda A, Malek N, Dudek B, Zeglen S, Wojarski J, Ochman M, Kucewicz E, Zembala M, Potempa J and Pyrc K: Infection with human coronavirus NL63 enhances streptococcal adherence to epithelial cells. J Gen Virol 92: 1358-1368, 2011.

131. Eijkelkamp BA, Morey JR, Neville SL, Tan A, Pederick VG, Cole N, Singh PP, Ong CY, Gonzalez de Vega R, Clases D, et al: Dietary zinc and the control of Streptococcus pneumoniae infection. PLoS Pathog 15: e1007957, 2019.

132. Coles CL, Sherchand JB, Khatry SK, Katz J, Leclerq SC, Mullany LC and Tielsch JM: Zinc modifies the association between nasopharyngeal Streptococcus pneumoniae carriage and risk of acute lower respiratory infection among young children in rural Nepal. J Nutr 138: 2462-2467, 2008.

133. Strand TA, Hollingshead SK, Julshamn K, Briles DE, Blomberg B and Sommerfelt H: Effects of zinc deficiency and pneumococcal surface protein A immunization on zinc status and the risk of severe infection in mice. Infect Immun 71: 2009-2013, 2003. 
134. Strand TA, Briles DE, Gjessing HK, Maage A, Bhan MK and Sommerfelt H: Pneumococcal pulmonary infection, septicaemia and survival in young zinc-depleted mice. Br J Nutr 86: 301-306, 2001.

135. Hamza SA, Mousa SM, Taha SE, Adel LA, Samaha HE and Hussein DA: Immune response of 23-valent pneumococcal polysaccharide vaccinated elderly and its relation to frailty indices, nutritional status, and serum zinc levels. Geriatr Gerontol Int 12: 223-229, 2012.

136. Mansouri F, Vaziri S, Janbakhsh A, Sayad B, Najafi F, Karimivafa SM, Kashef M and Azizi M: The effect of zinc on the Immune responses of pneumococcal vaccination in elderly. Int J Med Microbiol 10: 67-73, 2016.

137. Osendarp SJ, Prabhakar H, Fuchs GJ, van Raaij JM, Mahmud H, Tofail F, Santosham M and Black RE: Immunization with the heptavalent pneumococcal conjugate vaccine in Bangladeshi infants and effects of zinc supplementation. Vaccine 25 : 3347-3354, 2007.

138. Jacobsen FE, Kazmierczak KM, Lisher JP, Winkler ME and Giedroc DP: Interplay between manganese and zinc homeostasis in the human pathogen Streptococcus pneumoniae. Metallomics 3: 38-41, 2011.

139. McDevitt CA, Ogunniyi AD, Valkov E, Lawrence MC, Kobe B McEwan AG and Paton JC: A molecular mechanism for bacterial susceptibility to zinc. PLoS Pathog 7: e1002357, 2011.

140. Pasquet J, Chevalier Y, Pelletier J, Couval E, Bouvier D and Bolzinger MA: The contribution of zinc ions to the antimicrobial activity of zinc oxide. Colloids Surf A Physicochem Eng Asp 457: 263-274, 2014.

141. Bhattacharyya P, Agarwal B, Goswami M, Maiti D, Baruah S and Tribedi P: Zinc oxide nanoparticle inhibits the biofilm formation of Streptococcus pneumoniae. Antonie van Leeuwenhoek 111: 89-99, 2018

142. Reddy LS, Nisha MM, Joice M and Shilpa PN: Antimicrobial activity of zinc oxide ( $\mathrm{ZnO})$ nanoparticle against Klebsiella pneumoniae. Pharm Biol 52: 1388-1397, 2014.
143. Kadiyala U, Turali-Emre ES, Bahng JH, Kotov NA and VanEpps JS: Unexpected insights into antibacterial activity of zinc oxide nanoparticles against methicillin resistant Staphylococcus aureus (MRSA). Nanoscale 10: 4927-4939, 2018.

144. Ann LC, Mahmud S, Bakhori SKM, Sirelkhatim A, Mohamad D, Hasan H, Seeni A and Rahman RA: Antibacterial responses of zinc oxide structures against Staphylococcus aureus, Pseudomonas aeruginosa and Streptococcus pyogenes. Ceram Int 40: 2993-3001, 2014.

145. Sahu D, Kannan GM, Vijayaraghavan R, Anand T and Khanum F: Nanosized zinc oxide induces toxicity in human lung cells. ISRN Toxicol 2013: 316075, 2013.

146.Lin CD, Kou YY, Liao CY, Li CH, Huang SP, Cheng YW, Liao WC, Chen HX, Wu PL, Kang JJ, et al: Zinc oxide nanoparticles impair bacterial clearance by macrophages. Nanomedicine (Lond) 9: 1327-1339, 2014.

147. Bayle L, Chimalapati S, Schoehn G, Brown J, Vernet T and Durmort C: Zinc uptake by Streptococcus pneumoniae depends on both AdcA and AdcAII and is essential for normal bacterial morphology and virulence. Mol Microbiol 82: 904-916, 2011.

148. Brown LR, Caulkins RC, Schartel TE, Rosch JW, Honsa ES, Schultz-Cherry S, Meliopoulos VA, Cherry S and Thornton JA: Increased zinc availability enhances initial aggregation and biofilm formation of Streptococcus pneumoniae. Front Cell Infect Microbiol 7: 233, 2017.

149. Skalnaya MG and Skalny AV: Essential trace elements in human health: a physician's view. Publishing House of Tomsk State University, Tomsk, 2018.

This work is licensed under a Creative Commons Attribution-NonCommercial-NoDerivatives 4.0 International (CC BY-NC-ND 4.0) License. 